\title{
L-Carnitine Changes the Levels of Insulin-like Growth Factors (IGFs) and IGF Binding Proteins in Streptozotocin-induced Diabetic Rat
}

\author{
Young-Ran $\mathrm{HEO}^{1}$, Chang-Won $\mathrm{KANG}^{2}$ and Youn-Soo CHA ${ }^{1, *}$ \\ ${ }^{1}$ Department of Food Science $\mathcal{E}$ Human Nutrition and Institute for Molecular Biology and Genetics, \\ ${ }^{2}$ Bio-safety Research Institute, Chonbuk National University, Chonju 561-756, Korea
}

(Received January 9, 2001)

\begin{abstract}
Summary This study investigated the effects of L-carnitine on insulin-like growth factorI/II (IGF-I/II) and insulin-like growth factor binding proteins (IGFBPs) in streptozotocin (STZ)-induced diabetic rats. Each rat in the three L-carnitine-treated groups was injected subcutaneously with L-carnitine, 50 (D50), 100 (D100), or 200 (D200) mg/kg body weight every other day for four weeks, and animals in normal (N) and diabetic (DM) groups received saline by the same method. Diabetic rats had significantly lower carnitine concentrations in serum and liver compared with normal rats. Total carnitine concentrations were increased dose-dependently by carnitine treatment. Total IGF-I in serum from diabetic rats was increased dose-dependently by carnitine treatment, but was statistically significant only in the D200 group. The expression of liver IGF-I mRNA was lower in diabetic rats than in normal rats and increased by L-carnitine treatment. L-Carnitine treatment of diabetic rats had no effect on the levels of IGF-II in serum, liver, and kidney. Although the levels of IGF-II in serum and kidney of diabetic rats were increased in comparison with normal rats, IGF-II mRNA was not expressed in liver. Diabetic rats had markedly lower IGFBP-3 than normal rats did, and IGFBP-3 was increased by L-carnitine treatment. These results demonstrate that L-carnitine treatment of diabetic rats modulates the IGFs/IGFBPs axis. Especially noteworthy is that L-carnitine at a dose of $200 \mathrm{mg} / \mathrm{kg} / 48 \mathrm{~h}$ for four weeks was able to restore serum total IGF-I in STZ-induced diabetic rats to nearly normal levels.
\end{abstract}

Key Words IGFs, IGFBPs, carnitine, diabetes

Insulin-like growth factors (IGFs) are well known to have insulin-like action and growth-promoting mitogenic effects. Insulin and IGFs, which are involved in the pathogenesis of diabetes, have structural and functional homology with each other (1). IGFs are bound to specific binding proteins (IGFBPs) as they circulate in blood. Six types of IGFBPs have been found in serum and various fluids; they control distribution of the IGFs and regulate their half-life, availability, and activity (2, 3). IGFs and IGFBPs play an important role in controlling glucose homeostasis (4), and there is evidence to support their involvement in complications related to diabetes (5). Furthermore, experimental animal and human studies both suggest differences in the IGFs/ IGFBPs system between diabetic and normal states.

Carnitine ( $\beta$-hydroxy- $\gamma$-trimethylaminobutyric acid) is a small water-soluble quaternary amine that plays an important role in lipid catabolism where it serves as an essential cofactor for the transport of long-chain fatty acids, as acylcarnitine esters, across the inner mitochondrial membrane (6). Recent research suggests that besides carnitines role in the oxidation of fatty acids, it is also crucial in the regulation of carbohydrate metabolism (7). Several studies on carnitine metabolism have reported decreased plasma and liver carnitine concen-

* To whom correspondence should be addressed.

E-mail:cha8@moak.chonbuk.ac.kr trations in diabetic humans and experimental diabetic rats. It has been observed that carnitine administration has a hypoglycemic effect on diabetic rats $(8,9)$ and leads to an improvement in glucose metabolism through an insulin-sparing mechanism (10). Also, acetyl-L-carnitine at a dose of $150 \mathrm{mg} / \mathrm{kg} / \mathrm{d}$ given for one month normalizes nerve conduction velocity in streptozotocin (STZ)-induced diabetic rats with no adverse effect (11). Therefore carnitine might be useful as an adjunct therapy in the treatment of diabetes mellitus (12).

Hudson et al. (13) recently reported that IGF-I itself is capable of significantly increasing CPT activity. Therefore in this study we evaluated the effects of L-carnitine on the levels of IGFs and IGFBPs in STZ-induced diabetic rats.

\section{MATERIALS AND METHODS}

Experimental animals. Forty male Sprague-Dawley rats weighing $205.3 \pm 12.5 \mathrm{~g}$ were used. Diabetes was induced in 24 of the rats by a single intraperitoneal injection of STZ $(45 \mathrm{mg} / \mathrm{kg}$ body weight, Sigma Chemical Co., St. Louis, USA) and was confirmed by a determination of urinary glucose excretion. Diabetic rats were then randomly divided into four groups: the control group and three experimental groups for L-carnitine treatment. Each rat in the three L-carnitine-treated groups was given carnitine at doses of 50, 100, or 
$200 \mathrm{mg} / \mathrm{kg}$ body weight by subcutaneous injection every other day for four weeks, and animals in the control groups received saline by the same method. During the experimental periods (four weeks), the rats were fed an AIN-76 diet, housed in a laboratory maintained at a constant temperature $\left(23 \pm 2^{\circ} \mathrm{C}\right)$, and controlled in a 12-h light/dark cycle. The animals were given free access to food and water during the entire experimental period. At the end of this period, they were anesthetized following a 12-h fast. Blood samples were taken from the trunk after decapitation and centrifuged at $4^{\circ} \mathrm{C}$, $3,000 \mathrm{rpm}$ for $30 \mathrm{~min}$, and serum was separated and stored at $-70^{\circ} \mathrm{C}$ until assayed. Liver and kidney were removed and rinsed with a saline solution, wiped with paper towel, then homogenized with trifluroacetic acid solution (TFA) for total IGFs and centrifuged at $4^{\circ} \mathrm{C}$, $3,000 \mathrm{rpm}$ for $30 \mathrm{~min}$; the supernatant was separated and stored at $-70^{\circ} \mathrm{C}$ until assayed.

Carnitine assay. Total carnitine in serum and liver extracts were determined by the radioenzymatic procedure of Cederblad and Lindstedt (14), as modified by Sachan et al. (15). In this method all samples were hydrolyzed with $0.5 \mathrm{~mol} / \mathrm{L} \mathrm{KOH}$ for $60 \mathrm{~min}$ in a hot water bath at $65^{\circ} \mathrm{C}$. An aliquot of the neutralized supernatant was used to assay the total carnitine. In each sample, carnitine was assayed by using carnitine acetyl transferase (Sigma Chemical Co., St. Louis, MO, USA) to esterify the carnitine to a $\left[{ }^{14} \mathrm{C}\right]$ acetate from $\left[1-{ }^{14} \mathrm{C}\right]$ acetyl CoA (Amersham, Arlington Heights, IL, USA). The radioactivity of samples was determined in a Beckman LS3801 liquid scintillation counter (Beckman Instruments, Palo Alto, CA, USA).

IGF-I/II radioimmuno assay (RIA). Recombinant human IGF-I/II was iodinated to a specific radioactivity of $\left.150-300 \mathrm{Ci} / \mathrm{g},{ }^{125} \mathrm{I}\right]$ by a modification of the chloramin-T method. Serum and tissue IGFBPs were separated by the method of Lee and Henricks (16). Immunoreactive IGF-I/II was performed by the method of Lee et al. (17). Fifty $\mu \mathrm{L}$ of polyclonal IGF-I/II antibody diluted to $1: 1,000$ were added to $100 \mu \mathrm{L}$ of samples/ standard, then incubated for $1 \mathrm{~h}$ at room temperature. Next, $\left[{ }^{125}\right.$ I]-IGFs measuring $20,000 \mathrm{cpm}$ were added to the samples/standard and incubated for $18 \mathrm{~h}$ at $4^{\circ} \mathrm{C}$. All samples were centrifuged at $3,000 \times g$ for $30 \mathrm{~min}$. The supernatant was discarded, and radioactivity of the precipitate containing bound $\left[{ }^{125} \mathrm{I}\right]-\mathrm{IGFs}$ was detected in the gamma scintillation counter. All assays were performed in duplicate. Inter- and intra-assay coefficients of variation for IGFs were $8 \%$ and $10 \%$, respectively.

IGF-I/II mRNA expression assay by quantitative competitive reverse transcription and polymerase chain reaction (QC RT-PCR). Total RNA was separated, then quantified by the method of Fichera et al. (18). Briefly, total RNA was isolated from liver samples of all animals with TRIzol $^{\mathrm{TM}}$ Reagent (Gibco BRL, Basle, Switzerland), and the pellet was resuspended in DEPC water. The amount of total RNA was measured spectrophotometrically at $260 \mathrm{~nm}$. RT-PCR reaction was carried out as follows: Three ng of RNA resuspended with $4.1 \mu \mathrm{L}$ of diethylpyrocarbonate distilled water (DW) was mixed with reac- tion mixture containing $2 \mu \mathrm{L}$ of $5 \mathrm{X}$ transcription optimized buffer, $1 \mu \mathrm{L}$ of $0.1 \mathrm{M}$ DL-dithiothreitol (DTT), $1 \mu \mathrm{L}$ of $500 \mu \mathrm{M}$ dNTP, $1 \mu \mathrm{L}$ of random primer $(1 \mathrm{ng} / \mathrm{mL})$, $0.4 \mu \mathrm{L}$ of RNase inhibitor, and $0.5 \mu \mathrm{L}$ of transcriptase to $10 \mu \mathrm{L}$ of total volume and the incubation was prolonged for $1 \mathrm{~h}$ at $42^{\circ} \mathrm{C}$ and $10 \mathrm{~min}$ at $42^{\circ} \mathrm{C}$. Q-PCR reaction was then performed as follows: Ten $\mu \mathrm{L}$ of each sample containing $3 \mathrm{ng}$ of RT product, $1 \mu \mathrm{L}$ standard $(3.5 \mathrm{ng})$, and $6 \mu \mathrm{L}$ of DW was diluted in $50 \mu \mathrm{L}$ reaction buffer containing $5 \mu \mathrm{L}$ of $10 \mathrm{X}$ buffer, $5 \mu \mathrm{L}$ of $500 \mu \mathrm{M}$ dNTP, $3 \mu \mathrm{L}$ of $\mathrm{MgCl}_{2}, 1 \mu \mathrm{L}$ of IGF-I/II 5' primer, $1 \mu \mathrm{L}$ of IGF-I/II 3' primer, and $0.25 \mu \mathrm{L}$ of Taq (Qiagen, Hilden, Germany). The Q-PCR was started at $94^{\circ} \mathrm{C}$. One cycle consists of $1 \mathrm{~min}$ at $55^{\circ} \mathrm{C}$ and $1 \mathrm{~min}$ at $72^{\circ} \mathrm{C}$ for IGF-I and consists of $1 \mathrm{~min}$ at $58^{\circ} \mathrm{C}$ and $1 \mathrm{~min}$ at $72^{\circ} \mathrm{C}$ for IGF-II. The number of PCR cycles was 30 for both IGF-I and IGF-II. Ten $\mu \mathrm{L}$ of PCR products were run on a $2.5 \%$ agarose gel and dyed with ethidium bromide. The mean intensity of the target bands in agarose gel was measured with a Kodak camera (Eastman Kodak Company, Rochester, NY, USA).

Western ligand blotting (WLB). Samples were electrophoresed on $12 \%$ SDS-PAGE under nonreducing conditions by using the Mini-Protein, and proteins were electroplated onto a nitrocellulose membrane. The membrane was blocked with $1 \%$ BSA and incubated for $18 \mathrm{~h}$ at $4^{\circ} \mathrm{C}$ with $200,000 \mathrm{cpm}$ of $\left[{ }^{125} \mathrm{I}\right]$-IGFs in the buffer containing $1 \%$ BSA and $0.1 \%$ Tween 20. After extensive washing in cold buffer, the membrane was dried at room temperature. X-ray films were then exposed to the membranes at $-70^{\circ} \mathrm{C}$ for $7 \mathrm{~d}$ by the method of Hossenlopp et al. (19).

Statistical analysis. All values are expressed as group means \pm SD. The statistical significance of differences between groups was determined by Student's $t$ test and analysis of variance using the SAS version 6 (SAS Institute, Cary, NC, USA). When the $F$ test indicated differences between groups, the differences were separated by using Duncan's multiple range test.

\section{RESULTS}

Food intake was significantly higher in diabetic rats than in normal rats; however, weight gain was the same in both groups (Table 1). As shown in Table 2, total carnitine levels in serum and liver were significantly lower in diabetic rats than in normal rats. L-Carnitine treatment induced a dose-dependent increase in total carnitine concentrations in serum, but not in liver. L-Carnitine treatment at the $100 \mathrm{mg} / \mathrm{kg}$ and $200 \mathrm{mg} / \mathrm{kg}$ doses increased liver total carnitine concentrations, whereas the $50 \mathrm{mg} / \mathrm{kg}$ dose had no effect. Total IGF-I levels in serum and liver were lower in diabetic rats than in normal rats and increased dose-dependently with L-carnitine treatment. Total IGF-II levels in serum and kidney were higher in diabetic rats, but L-carnitine treatment had no effect on IGF-II levels (Table 3). Liver IGF-I mRNA expression (Fig. 1) was lower $(p<0.05)$ in diabetic rats than in normal rats and was increased by Lcarnitine treatment. IGF-II mRNA expression, however, was not detected in either normal or diabetic rats or in 
Table 1. Food consumption, body weight gain, and food efficiency ratio.

\begin{tabular}{|c|c|c|c|c|c|}
\hline & \multicolumn{2}{|c|}{ Control } & \multicolumn{3}{|c|}{ Carnitine-treated diabetes } \\
\hline & Normal & Diabetes & D50 & D100 & D200 \\
\hline Food consumption (g/d) & $16.4 \pm 1.51^{1, *}$ & $23.2 \pm 1.5$ & $22.8 \pm 2.6$ & $24.3 \pm 2.5$ & $23.7 \pm 4.4$ \\
\hline Weight gain $(\mathrm{g} / \mathrm{d})$ & $3.1 \pm 0.4$ & $3.0 \pm 1.0$ & $2.4 \pm 0.8$ & $2.8 \pm 1.5$ & $2.3 \pm 1.2$ \\
\hline Food efficiency ratio ${ }^{2}$ & $18.7 \pm 2.0^{*}$ & $12.7 \pm 3.5$ & $10.7 \pm 3.6$ & $11.7 \pm 6.3$ & $10.2 \pm 5.7$ \\
\hline
\end{tabular}

${ }^{1}$ Values are mean $(n=8) \pm S D$, *; values with normal rats are significantly different compared with corresponding values of diabetic control rat by Student's $t$-test at $p<0.05 .{ }^{2}$ The food efficiency ratio was calculated as weight gain/dietary intake during the experimental period. Dose (mg/kg body weight/48 h); D50 (dose 50), D100 (dose 100), D200 (dose 200).

Table 2. Total carnitine concentration in serum and liver.

\begin{tabular}{|c|c|c|c|c|c|}
\hline & \multicolumn{2}{|c|}{ Control } & \multicolumn{3}{|c|}{ Carnitine-treated diabetes } \\
\hline & Normal & Diabetes & D50 & D100 & D200 \\
\hline $\operatorname{Serum}(\mathrm{nm} / \mathrm{mL})$ & $81.9 \pm 13.6^{*}$ & $62.1 \pm 19.5^{b}$ & $112.4 \pm 29.5^{\mathrm{ab}}$ & $145.7 \pm 37.4^{\mathrm{ab}}$ & $167.8 \pm 57.5^{\circ}$ \\
\hline Liver ( $\mathrm{nm} / \mathrm{g}$ wet weight) & $305.2 \pm 18.1$ & $297.4 \pm 82.1^{\mathrm{b}}$ & $278.6 \pm 21.3^{b}$ & $366.8 \pm 50.1^{\mathrm{ab}}$ & $401.9 \pm 49.1^{\circ}$ \\
\hline
\end{tabular}

Values are mean $(n=8) \pm \mathrm{SD}$. Values with different superscripts are significantly different by ANOVA with Duncan's multiple range test at $p<0.05$. ; Values with normal rat are significantly different when compared with the corresponding values of diabetic control rat by Student's $t$-test at $p<0.05$. Dose (mg/kg body weight $/ 48 \mathrm{~h}$ ) D50 (dose 50), D100 (dose 100), D200 (dose 200).

Table 3. IGF-I and IGF-II concentrations in serum, liver, and kidney.

\begin{tabular}{|c|c|c|c|c|c|c|}
\hline & & \multicolumn{2}{|c|}{ Control } & \multicolumn{3}{|c|}{ Carnitine-treated diabetes } \\
\hline & & Normal & Diabetes & D50 & D100 & D200 \\
\hline Serum & T-IGF-I & $628 \pm 84.8^{*}$ & $242.8 \pm 38.8^{b}$ & $455.6 \pm 246^{\mathrm{ab}}$ & $571.2 \pm 109.4^{\mathrm{ab}}$ & $660.8 \pm 89.6^{\mathrm{a}}$ \\
\hline$(\mathrm{ng} / \mathrm{mL})$ & T-IGF-II & $12.53 \pm 1.2^{*}$ & $18.81 \pm 6.8$ & $18.54 \pm 5.57$ & $17.29 \pm 3.61$ & $16.78 \pm 1.97$ \\
\hline Liver & T-IGF-I & $73.6 \pm 11.52^{*}$ & $41.6 \pm 17.92$ & $49.92 \pm 10.24$ & $56.96 \pm 11.52$ & $57.6 \pm 18.56$ \\
\hline (ng/mL) & T-IGF-II & $18.1 \pm 3.5$ & $25.9 \pm 7.3$ & $28.5 \pm 8.0$ & $22.1 \pm 4.0$ & $21.5 \pm 2.2$ \\
\hline Kidney & T-IGF-I & $23.2 \pm 11.2$ & $26.4 \pm 10.4$ & $26.4 \pm 12.8$ & $27.2 \pm 9.6$ & $22.4 \pm 4.2$ \\
\hline$(\mathrm{ng} / \mathrm{mL})$ & T-IGF-II & $21.5 \pm 2.1^{*}$ & $34.9 \pm 4.9$ & $41.6 \pm 7.5$ & $42.5 \pm 13.8$ & $43.2 \pm 14.9$ \\
\hline
\end{tabular}

Values are mean $(n=8) \pm S D$. Values with different superscripts are significantly different by ANOVA with Duncan's multiplerange test at $p<0.05$. *; Values with normal rat are significantly different compared with corresponding values of diabetic control rat by Student's $t$-test at $p<0.05$. Dose (mg/kg body weight/d); D50 (dose 50), D100 (dose 100), D200 (dose 200), T-IGF-I; total insulin-like growth factor-I, T-IGF-II; total insulin-like growth factor-II.

L-carnitine-treated diabetic rats (data not shown). The patterns of serum IGFBPs analyzed by WLB are shown in Fig. 2, and 38-42 kDa (IGFBP-3), $34 \mathrm{kDa}$ (IGFBP-2), and $24 \mathrm{kDa}$ (IGFBP-4) were identified. The amount of IGFBP-3 was lower $(p<0.05)$ in diabetic rats than in normal rats, but it increased with L-carnitine treatment. The amount of IGFBP-2 was decreased in the Lcarnitine treated group.

\section{DISCUSSION}

This study was conducted to study the effects of Lcarnitine on the levels of IGFs and IGFBPs in STZ-induced diabetic rats. Several studies reported that poor glycemic control in diabetes is associated with reduced serum IGF-I levels $(4,5)$. The levels of total and free carnitine in serum are decreased in diabetes, and carnitine deficiency plays an important role in diabetes-related complications $(20)$.

Our results showed that the levels of serum total IGFI were increased in parallel with serum total carnitine concentrations induced by subcutaneous injections of L-carnitine.

The main source of circulating IGF-I is considered to be the liver (21). Increased total IGF-I level in serum may have been due to an increase of IGF-I production in the liver. The area ratios of IGF-I per standard bands were calculated by using area values based on a densitometric analysis (Fig. 1). In this study, the levels of IGFI and the expression of IGF-I mRNA in liver were both increased by L-carnitine treatment. These observations demonstrated that the treatment of STZ-induced diabetic rats with L-carnitine increases hepatic IGF-I 

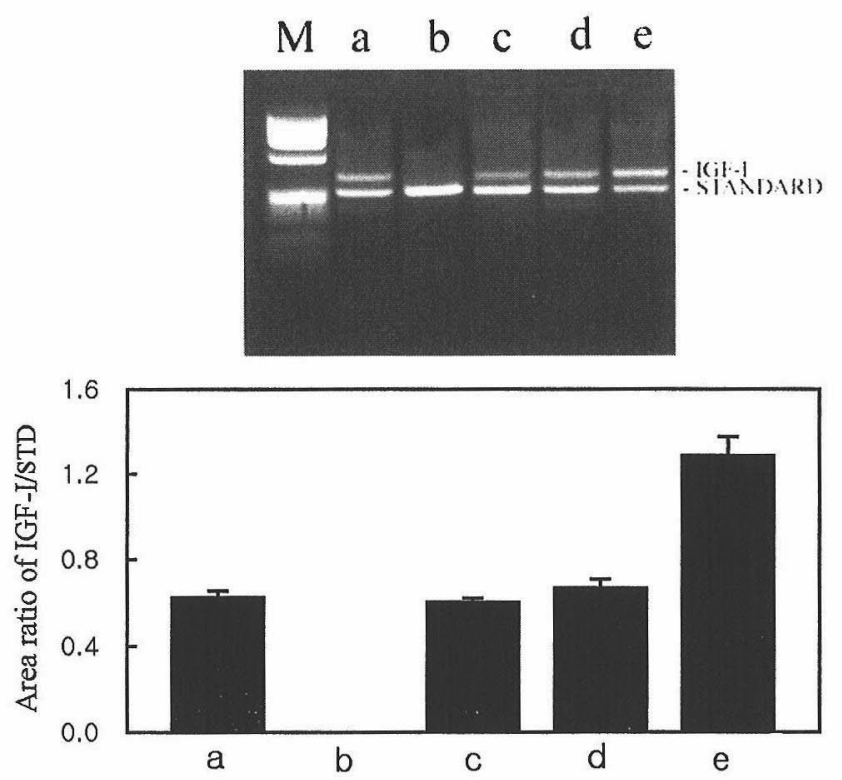

Fig. 1. IGF-I mRNA expression in liver. The radioactivity in each animal was quantified by a Bio-imaging Analyzer (BAS-2000, Fuji, Japan). The values are the means for eight animals \pm SD. ${ }^{*} p<0.05$ compared to the normal rats. Lane $\mathrm{M}$, marker; Lane a, normal; Lane b, diabetes; Lane c, dose 50; Lane d, dose 100; Lane e, dose 200.
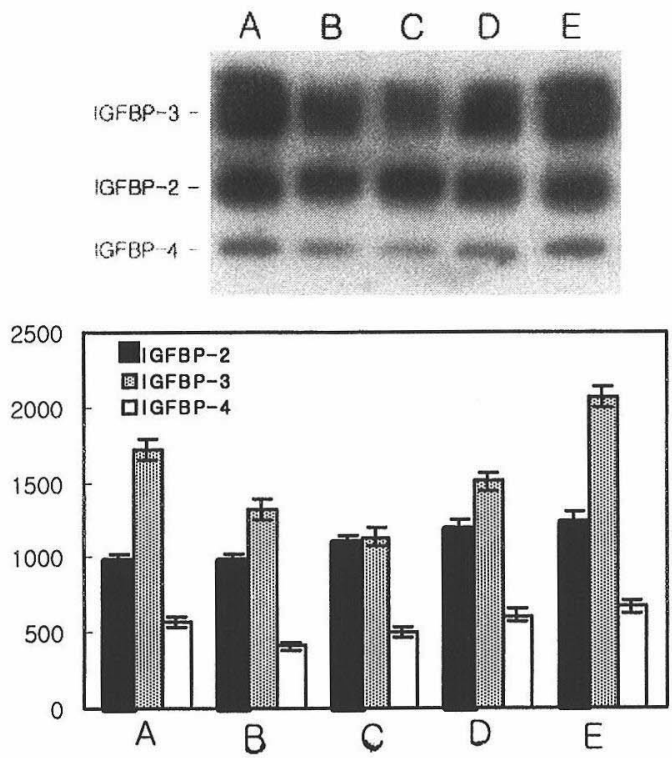

Fig. 2. IGFBPs pattern in serum of normal and streptozotocin-induced diabetic rats by Western ligand blotting (WLB). After quantitative analysis of protein, pooled samples were analyzed by WLB. Ten $\mu \mathrm{L}$ of samples were electrophoresed on $12 \%$ SDS-PAGE gel under nonreducing conditions. The proteins were transferred onto nitrocellulose filters, incubated with [ $\left.{ }^{125} \mathrm{I}\right]-\mathrm{IGF}-\mathrm{I}$, and exposed to X-ray film for $7 \mathrm{~d}$. The radioactivity in each animal was quantified by a Bio-imaging Analyzer (BAS-2000, Fuji). The values are the means for eight animals $\pm S D$. $* p<0.05$ compared to the normal rats. IGFBPs, insulin-like growth-factor binding proteins, Lane A, normal; Lane B, diabetes; Lane C, dose 50; Lane D, dose 100; Lane E, dose 200; IGFBP-3, 42 kDa; IGFBP-2, $34 \mathrm{kDa}$; IGFBP-4, $24 \mathrm{kDa}$.
mRNA expression, which results in increased IGF-I production in liver and eventually induces increased IGF-I level in serum. However, in contrast to the increased levels of IGF-I in liver, there was a decrease in IGF-I levels in kidney by treatment with L-carnitine.

A typical characteristic of the IGFs/IGFBPs axis in diabetic rats is that IGF-II levels are either increased or unchanged. In our results, IGF-II levels in serum and kidney from diabetic rats were increased in comparison with normal rats, but the IGF-II level in liver was not different between diabetic and normal rats. Also, there was no detectable IGF-II mRNA expression in either normal or diabetic rat liver. It has been reported that IGF-II expression is not continued after birth in rodents, unlike humans $(22,23)$. Therefore it can be assumed that the increase of IGF-II in serum from diabetic rat was not due to an increase of IGF-II production in liver. Other tissues may be involved. Recent studies have shown that the renal IGFs/IGFBPs axis is altered in diabetes, suggesting that these changes may be implicated in alterations in renal functions and morphology that accompany diabetes. Because kidney from diabetic rats had a higher IGF-II level than in normal rats, the changes of serum IGF-II level might have been due to an increase in renal synthesis. In this study, we did not determine IGF-II expression in kidney; therefore further work is necessary to determine the relationship between IGF-II increase and renal synthesis in diabetes.

The changes in IGFBPs patterns in serum were analyzed by WLB. The amount of IGFBP-3 was markedly decreased; however the amount of IGFBP-2 and IGFBP4 were not changed in serum from STZ-induced diabetic rats in comparison with normal rats. These results were partially explained by the findings of Luo and Murphy (24), who found a significant increase in the amount of hepatic IGFBP-1 and IGFBP-2 mRNA at one month and three months after the onset of diabetes. In contrast to the increase in hepatic IGFBP-1 and IGFBP2 mRNA was a significant decrease in hepatic IGFBP-3 mRNA and no significant difference in hepatic IGFBP-4 mRNA levels in diabetic rats. These results may suggest that changes in serum IGFBP-3 in diabetic rats were due to changes in the hepatic IGFBP-3 pattern, and these changes may be regulated at the transcriptional level. The treatment of L-carnitine resulted in a dose-dependent increase in IGFBP-3, but there were no changes in IGFBP-2 and IGFBP-4. This study is the first to demonstrate an involvement of carnitine with the IGF system. The central role of carnitine on lipid metabolism is well known, but the role of carnitine in carbohydrate metabolism is less well understood. It has been reported that L-carnitine stimulates the activity of the pyruvate dehydrogenase complex by decreasing the intramitochondrial acetyl-CoA/CoA ratio through the trapping of acetyl groups. The simultaneous reduction of acetyl-CoA levels in the cytosol further contributes to activate the glycolytic pathway (25). Recently, De Gaetano et al. (12) demonstrated that increased circulating carnitine did not alter the insulin sensitivity index or insulin/c-peptide, but glucose disposal from 
plasma was significantly increased with carnitine in healthy volunteers. They suggested that carnitine might play a role in the therapy of diabetes mellitus. Our results could suggest that L-carnitine treatment of STZ-induced diabetic rats also improved glucose metabolism via modulation of the IGFs and IGFBPs levels. The esterification of long-chain fatty acids to carnitine by CPT-I is an important and possibly rate-limiting step in fatty acid oxidation (26). The increase in CPT-I activity in STZ-induced diabetic rats was expected and is an effect seen in various species when fatty acid oxidation is increased $(27,28)$. CPT-I activity was not changed by Lcarnitine treatment at the $50 \mathrm{mg} / \mathrm{kg}$ dose, but it had a tendency to increase at the $100 \mathrm{mg} / \mathrm{kg}$ dose and was reduced at the $200 \mathrm{mg} / \mathrm{kg}$ dose (data not shown). If subsequent research does demonstrate an effect of carnitine supplementation of STZ-induced rats on CPT-I activity, that will be an important development deserving further investigation.

In conclusion, these results demonstrate that L-carnitine treatment of STZ-induced diabetic rats modulates the IGFs/IGFBPs axis. It is especially noteworthy that $\mathrm{L}-$ carnitine at a dose of $200 \mathrm{mg} / \mathrm{kg}$ body weight $/ 48 \mathrm{~h}$ for four weeks restores serum concentrations of total IGF-I to near normal levels.

\section{Acknowledgements}

The authors wish to thank Chonbuk National University for its support through a grant from the PostDoctoral Program (1999).

\section{REFERENCES}

1) Cohen P, Rosenfeld RG. 1994. Physiologic and clinical relevance of the insulin-like growth factor binding proteins. Curr Opin Pediatr 6: 462-467.

2) Carroll PV, Umpleby M, Alexander EL, Egel VA, Callison KV, Sonksen PH, Russell-Jones DL. 1998. Recombinant human insulin-like growth factor-I (rhIGF-I) therapy in adults with type 1 diabetes mellitus; effects on IGFs, IGF-binding proteins, glucose levels and insulin treatment. Clin Endocrinol 49: 739-746.

3) Kostecka Y, Blahovee J. 1999. Insulin-like growth factor binding proteins and their functions (minireview). Endocr Regul 33: 90-94.

4) Moxley RT III, Arner P, Moss A. 1990. Acute effects of insulin-like growth factor I and insulin on glucose metabolism in vivo. Am J Phsiol 259: E561-E567.

5) Spagnoli A, Chiarelli F, Vorwerk P, Boscherini B, Rosenfeld RG. 1999. Evaluation of the components of insulin-like growth factor (IGF)-IGF binding protein (IGFBP) system in adolescents with type I diabetes and persistent microalbuminuria: relationship with increased urinary excretion of IGFBP-3 $18 \mathrm{kD} \mathrm{N}$-terminal fragment. Clin Endocrinol 51: 587-596.

6) Tein I, Bukovac SW, Xie ZW. 1996. Characterization of the human plasmalemmal carnitine transpoter in cultured skin fibroblasts. Arch Biochem Biophys 329: 145-155.

7) Lopaschuk G. 2000. Regulation of carbohydrate metabolism in ischemia and reperfusion. Am Heart J 139: s115-s119.

8) Paulson DJ, Schmidt MJ, Traxler JS, Ramacci MT, Shug
AL. 1984. Improvement of myocardial function in diabetic rats after treatment with L-carnitine. Metabolism 33: 358-363.

9) Rodrigues B, Kiang H, McNeill JH. 1988. Effect of L-carnitine treatment on lipid metabolism and cardiac performance in chronically diabetic rats. Diabetes 37: 1358-1364.

10) Grandi M, Pederzoli S, Sacchetti C. 1997. Effect of acute carnitine adminitration on glucose insulin metabolism in healthy subjects. Inter J Clin Pharm Res 17: 143147.

11) Soneru IL, Khan T, Orfalian Z, Abraira C. 1997. AcetylL-carnitine effects on nerve conduction and glycemic regulation in experimental diabetes. Endocr Res 23: 27-36.

12) De Gaetano A, Mingrone G, Castagneto M, Calvani M. 1999. Carnitine increases glucose disposal in humans. J Am Coll Nutr 18: 289-295.

13) Hudson EK, Wang D, Bieber LL, Buja LM, McMillin JB. 1996. Increased carnitine palmitoyltransferase in cardiac myocytes is mediated by insulin growth factor I. Am J Physiol 271: H422-H427.

14) Cederblad G, Lindstedt S. 1972. A method for the determination of carnitine in the picomole range. Clin Chim Acta 37: 235-243.

15) Sachan DS, Rhew TH, Ruark RA. 1984. Aameliorating effects of carnitine and its precursors on alcohol-induced fatty liver. Am J Clin Nutr 39: 499-502.

16) Lee CY, Henricks DM. 1990. Comparisions of various acidic treatments of bovine serum on insulin-like growth factor-I immunoreactive and binding activity. $J$ Endocrinol 127: 139-148.

17) Lee DY, Kang CW, Kim JS. 1996. $\mathrm{Ca}^{2+}$ effects on synthesis and secretion of insulin-like growth factor (IGF-I) and IGF-binding proteins by the perfused rat liver. $J$ Kor Soc Endocrinol 11: 189-198.

18) Fichera E, Liang S, Xu Z, Guo N, Mineo R, FujitaYamaguchi Y. 2000. A quantitative reverse transcription and polymerase chain reaction assay for human IGF-II allows direct comparison of IGF-II mRNA levels in cancerous breast, bladder, and prostate tissues. Growth Horm IGF Res 10: 61-70.

19) Hossenlopp P, Seurin D, Segovia-Quinson B, Hardouin S, Binoux M. 1986. Analysis of serum insulin-like growth factor binding proteins using western blotting: use of the method for titration of the binding proteins and competitive binding studies. Anal Biochem 154: 138-143.

20) Tamamogullari N, Silig Y, Icagasioglu S, Atalay A. 1999. Carnitine deficiency in diabetes mellitus complications. J Diabetes Complicat 13: 251-253.

21) Rosen CJ, Pollak M. 1999. Circulating IGF-I: New perspectives for a new century. TEM 10: 136-141.

22) Gray A, Tam TJ, Dull J, Hayflick J, Pintar J, Cavenee WK, Koufos A, Ullrich A. 1987. Tissue specific and developmentally regulated transcription of the insulin-like growth factor 2 gene. DNA 6: 283-295.

23) O'Dell SD, Day INM. 1998. Molecules in focus insulinlike growth factor II (IGF-II). Int J Biochem Cell Biol 30: 767-771.

24) Luo J, Murphy LJ. 1992. Differential expression of the insulin-like growth factor binding proteins in spontaneously diabetic rats. J Mol Endocrinol 8: 155-163.

25) Lysiak W, Lilly K, DiLisa F, Toth PP, Bieber LL. 1988. Quantitation of the effect of L-carnitine on the levels of 
acid-soluble short-chain acyl-CoA and CoASH in rat heart and liver mitochondria. J Biol Chem 263: 11511156.

26) Knudsen J. 1990. Acyl-coA binding protein and its relation to fatty acid-binding protein; An overview. Mol Cell Biochem 98: 217-223.

27) Cook GA, Gamblle SM. 1987. Regulation of carnitine palmitoyltransferase by insulin results in decreased activity and decreased apparent $\mathrm{K} 1$ values for malonylCoA. J Biol Chem 262: 2050-2055.

28) Daily JW III, Hongu N, Mynatt RL, Sachan DS. 1998. Choline supplementation increases tissue concentrations of carnitine and lowers body fat in guinea pigs. $J$ Nutr Biochem 9: 44-47. 